\title{
Four Garlic Viruses Identified by Reverse Transcription-Polymerase Chain Reaction and Their Regional Distribution in Northern Japan
}

\author{
Miyuki Takaichi, Mika Yamamoto, Takayuki Nagakubo, and Kenji Oeda, Biotechnology Laboratory, Sumitomo \\ Chemical Co. Ltd., 4-2-1 Takatsukasa, Takarazuka, Hyogo 6658555, Japan
}

\begin{abstract}
Takaichi, M., Yamamoto, M., Nagakubo, T., and Oeda, K. 1998. Four garlic viruses identified by reverse transcription-polymerase chain reaction and their regional distribution in northern Japan. Plant Dis. 82:694-698.

A specific and highly efficient indexing method for four major garlic viruses, GV1 carlavirus, GV2 potyvirus, onion yellow dwarf virus (OYDV), and mite-borne mosaic virus, was developed using the reverse transcription-polymerase chain reaction method (RT-PCR). When specific primers were synthesized to amplify the coat protein genes of these viruses, the amplified PCR bands had the same expected sizes. This indexing method can be performed using an extremely small amount of leaf tissue $(50 \mathrm{mg})$ to obtain reproducible data. Diseased garlic plants collected from five fields in northern Japan were tested using this method. As GV2 was detected in all the fields, and high frequency of disease symptoms was obtained in the case of heavy infection, GV2 may well be a major garlic virus in this region. By contrast, GV1 was detected in only one of the five fields. OYDV and mite-borne mosaic viruses were also detected in various fields and at different frequencies. Judging from the virus indexing data and the disease symptoms, these two viruses appeared to cause severe symptoms in the case of a mixed infection with GV2. The frequency of virus re-infection to virus-free clones was low in isolated fields, and GV2 was the major virus that re-infected virus-free clones.
\end{abstract}

Additional keywords: Allium sativum, garlic latent virus (GLV), garlic mosaic virus (GMV), leek yellow stripe virus (LYSV)

Garlic (Allium sativum L.) is one of the most important Allium plants widely cultivated throughout the world. A significant reduction in yield and quality due to virus infection is now a serious economic problem $(6,7,15,24)$. In many cases, garlic plants are infected with a variety of viruses, but elimination of these viruses is difficult because this crop is propagated through bulbs $(4,25)$.

Potyvirus, carlavirus, and mite-borne mosaic virus have been detected in diseased garlic (22). A potyvirus is considered to cause a mosaic symptom, and several potyviruses are known to infect garlic $(4,20)$. Onion yellow dwarf virus (OYDV), leek yellow stripe virus (LYSV), and other unknown potyviruses were observed in garlic plants collected from European countries (25). OYDV and LYSV are considered to be the major garlic potyviruses. Both viruses were detected in south and southeast Asia (2), Italy (3), Israel (9), Venezuela (11), France (12), Java (17), and Australia (18). OYDV is detected at a high frequency in these areas, but LYSV is rare.

Corresponding author: Kenji Oeda

E-mail: oeda@tziris1.sumitomo-chem.co.jp

Accepted for publication 11 February 1998.

Publication no. D-1998-0323-02R

(C) 1998 The American Phytopathological Society
Two potyviruses have been found in Japan $(1,10)$, but the virus groups and distribution have not been documented. Mohamed and Young (13) and Dewan et al. (5) also noted garlic yellow streak virus (GYSV) in New Zealand, but the homology to other potyviruses was not given attention.

Carlaviruses detected in diseased garlic plants $(3,21)$ were not considered to cause severe symptoms in the case of single infection (25). However, there was extensive damage when carlaviruses and potyviruses were mix-infected in the garlic plants $(1,10)$.

Mite-borne mosaic viruses, which have rod-shaped particles similar to potyviruses, also cause weak symptoms in garlic plants $(23,26)$. Interestingly, the gene organizations of these viruses are closely related to those of potexvirus and carlavirus (16).

In many cases, these viruses are mix-infected in garlic plants. Therefore, it is difficult to obtain pure garlic virus particles from diseased garlic plants and also to prepare specific antibodies against garlic virus coat proteins. Immunoassay is unable to identify each virus because several viruses are cross-reactive against prepared antibodies.

Recently, cDNA clones coding for the coat protein $(\mathrm{CP})$ of garlic viruses were isolated, and their nucleotide sequences were determined. In our previous study, we determined the nucleotide sequences of the
$\mathrm{CP}$ genes of a carlavirus (GV1) and a potyvirus (GV2) (14). Four independent viral cDNA clones were isolated from new miteborne mosaic viruses, and the nucleotide sequences were also determined by Sumi et al. (16). They also reported that these viruses could be detected by RT-PCR (19). The nucleotide sequence of the cDNA coding for the coat protein of OYDV has also been documented (8).

We now report an efficient and convenient virus indexing method using reverse transcription-polymerase chain reaction (RT-PCR). At least four garlic viruses, GV1, GV2, OYDV, and mite-borne mosaic viruses, can be distinguished by this method. The regional distribution of these four viruses was investigated in Aomori Prefecture of northern Japan, the largest area of garlic production in Japan.

\section{MATERIALS AND METHODS}

Plant samples. Garlic cloves of cv. Howaito-roppen were randomly collected from eight fields of seven regions (A to $\mathrm{G}$ ) in Aomori Prefecture. Garlic cloves from fields F, G1, and G2 are virus-free clones and were cultivated in open fields for 3 to 5 years. Garlic cloves from the other fields (A to E) were cultivated for continuous annual production for more than 20 years. Ten to 14 cloves per site were cultivated in a greenhouse. At 3 to 4 weeks after germination, the frequency of viral disease

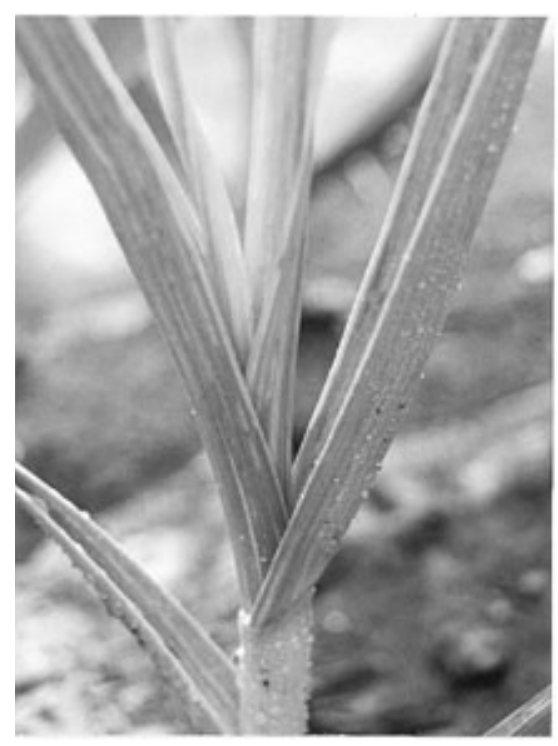

Fig. 1. Garlic leaves with yellow mosaic symptoms on the undersides. 
symptoms was determined and the degree of disease symptoms was classified into four grades by visual examination: heavy $(\mathrm{H})$, medium $(\mathrm{M})$, light $(\mathrm{L})$, and none $(\mathrm{N})$ (Table 1).

Preparation of total RNAs and cDNA synthesis. Fifty $\mathrm{mg}$ of plant material was crushed in liquid nitrogen, and total RNA was extracted with $1 \mathrm{ml}$ of ISOGEN (Nippon Gene) at room temperature. Chloroform $(0.2 \mathrm{ml})$ was added to the extract, and the mixture was vortexed for $15 \mathrm{~s}$, then total RNA was further extracted for $3 \mathrm{~min}$. The reaction mixture was centrifuged at $12,000 \mathrm{rpm}$ for $10 \mathrm{~min}$ at $4^{\circ} \mathrm{C}$. The total RNA fraction in the aqueous layer was precipitated with $0.5 \mathrm{ml}$ of isopropanol for $5 \mathrm{~min}$ at room temperature and recovered by centrifugation for $10 \mathrm{~min}$ at $4^{\circ} \mathrm{C}$. The precipitate was rinsed twice with ethanol and resuspended in $10 \mu \mathrm{l}$ of distilled water.

Twenty $\mu \mathrm{l}$ of the first strand of cDNA was synthesized from $8.5 \mu \mathrm{l}$ (under $5 \mu \mathrm{g}$ ) of the total RNA solution using an oligo(dT) primer and a cDNA synthesis kit (First Strand cDNA Synthesis Kit, Amersham, Little Chalfont, Buckinghamshire, Eng.), according to the supplier's instructions.

Primer design and synthesis. Oligonucleotide primers for amplification of GV1, GV2 (14), and OYDV (8) were designed to amplify their coat protein (CP) genes. 1L1 and $1 \mathrm{~L} 2$ were designed to hybridize the $5^{\prime}$ regions of the $\mathrm{CP}$ gene of GV1; whereas $1 \mathrm{R} 1$ and $1 \mathrm{R} 2$ were designed to hybridize to the $3^{\prime}$ region. $2 \mathrm{~L} 1$ and $2 \mathrm{~L} 2$ were located in the $5^{\prime}$ region of the $\mathrm{CP}$ gene of GV2. 2R1 and $2 \mathrm{R} 2$ are complementary to the $3^{\prime}$ region of this gene. OL1/OL2 and OR1/OR2 were designed to hybridize to the $5^{\prime}$ and the $3^{\prime}$ region of the CP gene of OYDV (8), respectively. The primers used for amplification of mite-borne mosaic viruses were the same as those used by Tsuneyoshi and Sumi (19). RT1 (5'-CCTGCTAAGCTATATGCTGA-3') to the $5^{\prime}$ region and RT2 (5'-GTAAGTTTAGCGATATCAAC-3') to
A. GV1: Carlavirus
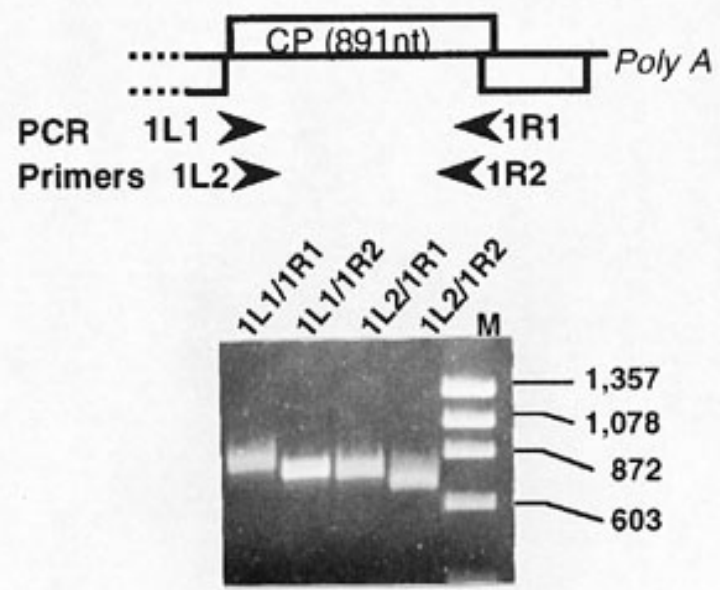

C. OYDV: Potyvirus
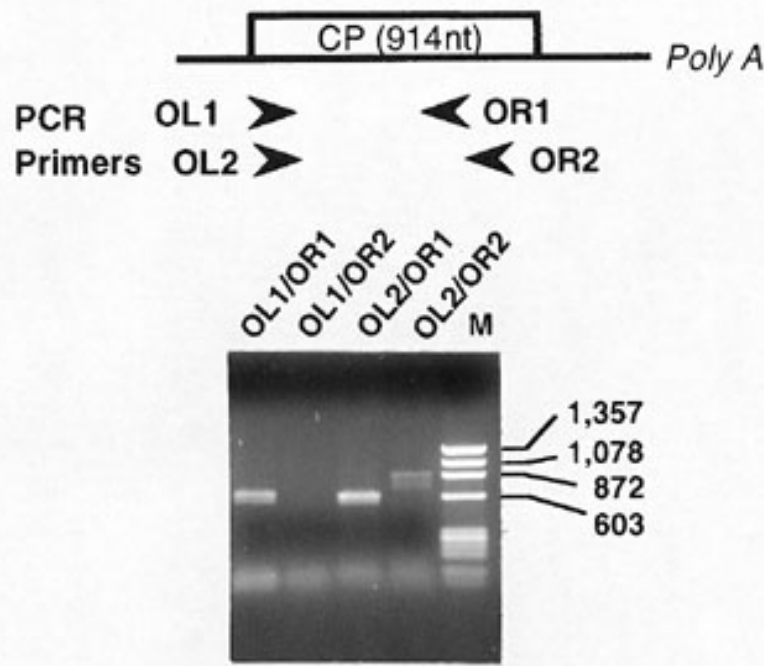

B. GV2: Potyvirus
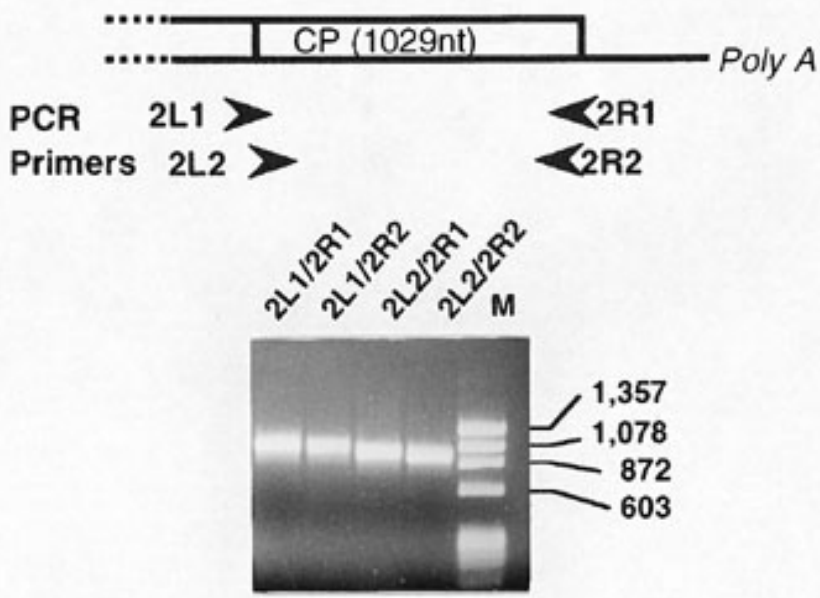

\begin{tabular}{lll} 
Primer & \multicolumn{1}{c}{ Nucleotide sequence } & CP gene \\
& & \\
1L1 & ATGCAAAACCTGCCTACCCG & +31 \\
1L2 & TTGGCGTGATGGATCGTGAG & +101 \\
1R1 & GGAAAACATCCGAAGAAGCCA & +863 \\
1R2 & CTGGGATTCTTCGCCAGAG & +804 \\
& & \\
2L1 & GGGTTCTTGAACAAGCACCG & -176 \\
2L2 & CCGATTGTGAGGCAACGGAA & -89 \\
2R1 & GATGGTGCATCCGTGCATTC & +847 \\
2R2 & ACATGTGCTGTGTGCTCTC & +824 \\
& & \\
OL1 & CGAAGCAAATTGCCAAGCAG & +1 \\
OL2 & GATAAGGATGTGGATGCAGG & +25 \\
OR1 & CGATTAGCTGCCCCTCTAAC & +626 \\
OR2 & TTCGTTTGCCACAACTGGTG & +857
\end{tabular}

Fig. 2. Polymerase chain reaction (PCR) primers for amplification of the coat protein (CP) genes of (A) GV1 carlavirus, (B) GV2 potyvirus, and (C) onion yellow dwarf virus (OYDV) together with the nucleotide sequences of PCR primers. Combinations of primers for detection of GV1 CP gene, 1L1/1R1, 1L1/1R2, 1L2/1R1, and 1L2/1R2, are designed to amplify 833, 774, 763, and 704 bp fragments, respectively. Primers of GV2 CP gene, 2L1/2R1, 2L1/2R2, 2L2/2R1, and 2L2/2R2, are designed to amplify 1,023, 1,000, 936, and $913 \mathrm{bp}$ fragments, respectively. Primers of OYDV CP gene, OL1/OR1, OL1/OR2, OL2/OR1, and OL2/OR2, are designed to amplify 625, 856, 601, and 835 bp fragments, respectively. Specific bands of the expected length were amplified in all combinations, except for OL1/OR2 primers. M indicates molecular makers. 
the $3^{\prime}$ region of the $\mathrm{CP}$ gene of mite-borne mosaic viruses were synthesized, according to reported data (19). All primers with 20 or 21 nucleotides were synthesized using an $\mathrm{ABI}$ synthesizer.

PCR. cDNA preparation $(0.5 \mu \mathrm{l})$ was mixed with $2.5 \mu$ of $10 \times$ reaction buffer, 2 $\mu \mathrm{l}$ of dNTP mixture, $0.125 \mu \mathrm{l}$ of rTaq, $17.375 \mu \mathrm{l}$ of distilled water, and $1.25 \mu \mathrm{l}$ of upstream and downstream primers (20 $\mathrm{pmol} / \mu \mathrm{l})$ for DNA amplification, using PCR kits (Takara Co. Ltd., Otsu, Shiga, Japan). The reaction mixture was subjected to 27 cycles of PCR. Samples were denatured at $95^{\circ} \mathrm{C}$ for $1 \mathrm{~min}$, annealed at $57^{\circ} \mathrm{C}$ for $1 \mathrm{~min}$, and extended at $72^{\circ} \mathrm{C}$ for $1 \mathrm{~min}$. The resulting reaction mixture was analyzed by $1 \%$ agarose gel electrophoresis (10 $\mu \mathrm{l}$ of reaction mixture per lane).

\section{RESULTS}

Virus symptoms. Yellow mosaic symptoms were observed on the lower surface of garlic leaves (Fig. 1). The degree of disease symptoms was classified into four grades: heavy, medium, light, and none (Table 1). The frequency of symptomatic plants varied from 58 to $90 \%$ in the case of local cloves. Heavy disease symptoms were found in samples $\mathrm{A}$ and $\mathrm{E}$, where the frequency of symptomatic plants was very high. Samples G1 and G2, derived from meristem tip culture and cultivated for 3 years in the open fields, showed no symptoms. Sample F, cultivated for 5 years, also consisted of virus-free clones. The frequency of symptomatic plants was $40 \%$, and the degree of disease symptoms was moderate.

Primer design and PCR conditions for specific DNA amplification. GV1, GV2, and OYDV have individual $\mathrm{CP}$ genes in the middle of their genomes, and virusspecific sequences can be selected in the amino-terminal and carboxy-terminal ends of their CPs. These positions and nucleotide sequences were selected so that all PCR experiments could be performed at the same annealing temperature $\left(57^{\circ} \mathrm{C}\right)$.

Four PCR primers were synthesized for GV1 detection. Primer combinations of 1L1/1R1, 1L1/1R2, 1L2/1R1, and 1L2/1R2 amplified the specific DNA bands of 833 , 774,763 , and 704 bp fragments, respectively. Each of the 20 pmol primers was used to amplify $1 \mathrm{ng}\left(4.5 \times 10^{-16}\right.$ mole $)$ of GV1 cDNA (pGLA-9 DNA) (Fig. 2A).

Similarly, primer combinations of 2L1/2R1, 2L1/2R2, 2L2/2R1, and 2L2/2R2 amplified specific fragments of 1,023 , $1,000,936$, and $913 \mathrm{bp}$ in length from $1 \mathrm{ng}$ of GV2 cDNA (pGMA-2 DNA, $5.5 \times 10^{-16}$ mole) (Fig. 2B). Four combinations of primers of OL1/OR1, OL1/OR2, OL2/OR1, and OL2/OR2 were also designed to index OYDV potyvirus. When PCR amplification was performed on $0.5 \mu \mathrm{l}$ (about 0.1 ng) of cDNA synthesized from the total RNA of the diseased plant as a template, a single band with the expected mobility was amplified in each combination of primers, except for OL1/OR2 primers (Fig. 2C). To detect mite-borne mosaic viruses, we synthesized the primers of RT1/RT2 according to the nucleotide sequence of the reported data (19). When DNA amplification was attempted using $0.5 \mu \mathrm{l}$ (about $0.1 \mathrm{ng}$ ) of the cDNA synthesized from the total RNA of a diseased plant, a single band with the ex-

pected mobility (about $180 \mathrm{bp)}$ was amplified (data not shown).

Indexing of garlic viruses. We selected 1L1/1R2, 2L1/2R1, OL2/OR1, and RT1/RT2 primers for PCR detection of GV1, GV2, OYDV, and mite-borne mosaic viruses, respectively. Twelve garlic plants were randomly collected from field $\mathrm{A}$ and tested for four virus infections. GV1, GV2,

Table 1. Plant samples used for virus indexing using reverse transcription-polymerase chain reaction

\begin{tabular}{llccl}
\hline Region & Source $^{\text {a }}$ & Plants cultivated & $\begin{array}{c}\text { Plants with } \\
\text { symptoms }\end{array}$ & $\begin{array}{l}\text { Degree of } \\
\text { symptoms }\end{array}$ \\
\hline A & Local & 12 & 8 & Heavy \\
B & Local & 12 & 9 & Medium \\
C & Local & 12 & 7 & Medium \\
D & Local & 14 & 12 & Medium \\
E & Local & 10 & 9 & Heavy \\
F & Virus free & 10 & 4 & Light \\
G1 & Virus free & 12 & 0 & None \\
G2 & Virus free & 12 & 1 & None \\
\hline
\end{tabular}

a Virus-free plants were cultivated in an open field for $3(\mathrm{G})$ or $5(\mathrm{~F})$ years.

\section{sample number}

\section{$\begin{array}{lllllllllllllll}1 & 2 & 3 & 4 & 5 & 6 & 7 & 8 & 9 & 10 & 11 & 12 & \mathrm{~N} & \mathrm{P} & \mathrm{M}\end{array}$}

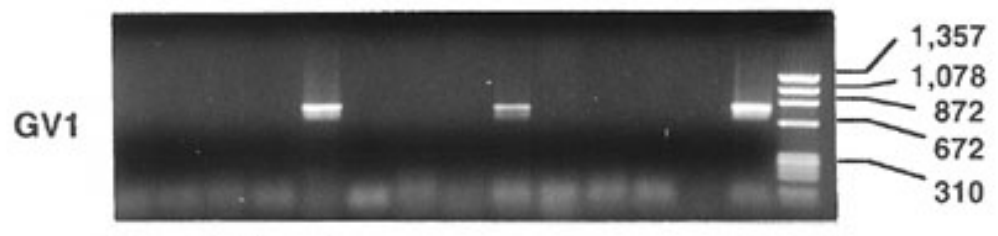

GV2
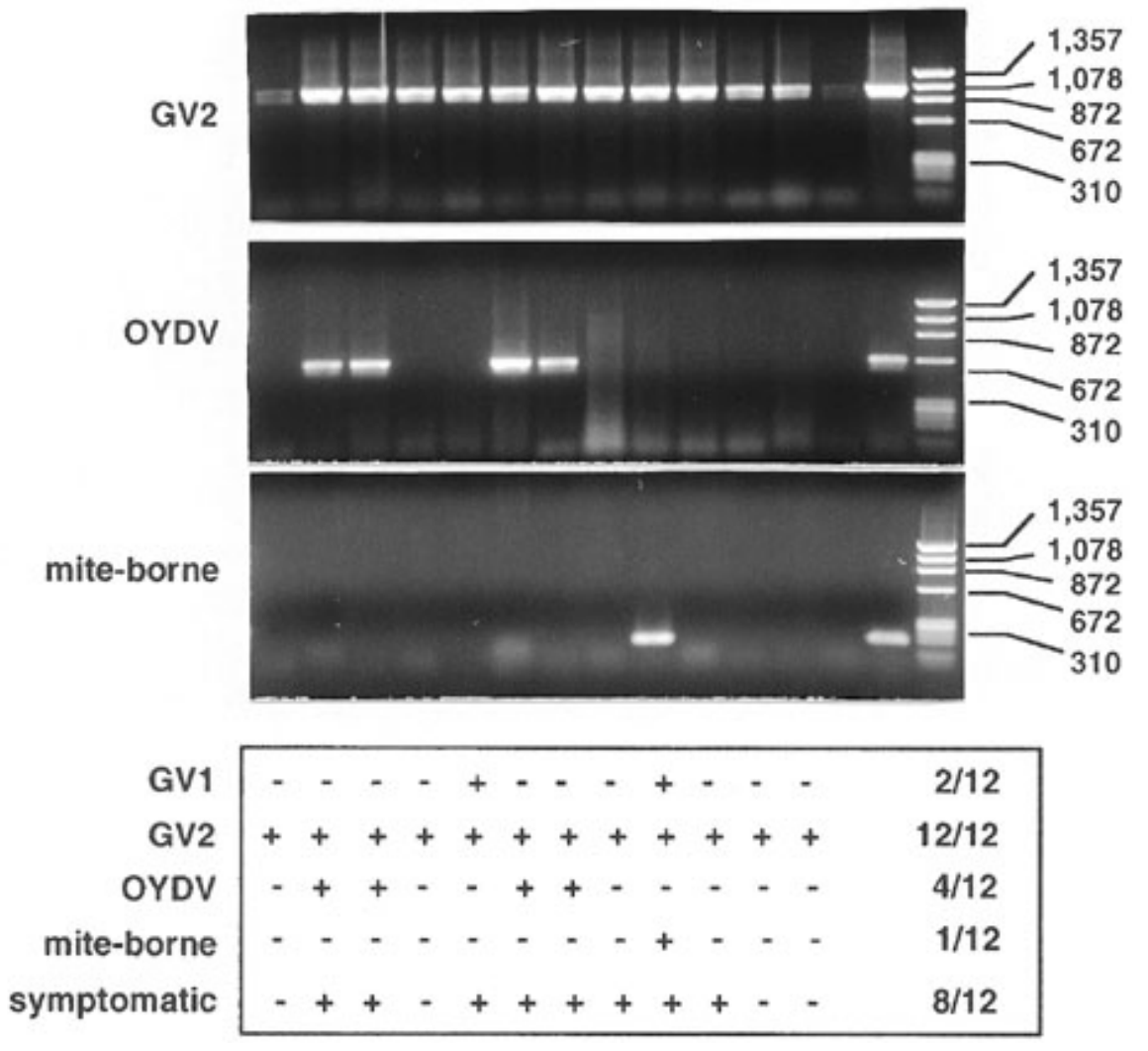

Fig. 3. GV1 carlavirus, GV2 potyvirus, onion yellow dwarf virus (OYDV), and mite-borne mosaic viruses were detected by reverse transcription-polymerase chain reaction (RT-PCR). Twelve samples were collected from garlic plants cultivated in field $\mathrm{A}$. M indicates molecular markers, and $\mathrm{N}$ and $\mathrm{P}$ are negative and positive controls, respectively. 
OYDV, and mite-borne mosaic viruses were detected in this experiment (Fig. 3). GV2 was detected in all samples; whereas GV1, OYDV, and mite-borne mosaic viruses were detected in 2,4 , and 1 samples out of 12 plants, respectively. Two potyviruses, GV2 and OYDV, were detected from plants 2, 3, 6, and 7. Both GV2 potyvirus and GV1 carlavirus infected plant 5; whereas three viruses, GV2 potyvirus, GV1 carlavirus, and mite-borne mosaic virus, infected plant 9. Only GV2 was detected in the remaining plants $(1,4,8$, 10,11 , and 12). Thus, four different viruses can be detected using RT-PCR, and several patterns of virus infection were obtained from this field.
Regional distribution of four viruses from eight fields in Aomori Prefecture. Garlic plants from eight fields of seven regions in Aomori Prefecture were tested by RT-PCR (Figs. 4 and 5). Local cloves were continuously cultivated in fields A to $\mathrm{E}$, and the frequency of disease symptoms was fairly high (60 to 90\%). GV2 potyvirus was detected at a high frequency (75 to $100 \%$ ). All samples were infected with GV2 in fields A and E. Thus, GV2 is the most common garlic virus in Aomori Prefecture, as determined based on the sets of primers used. The infection frequency of OYDV was estimated to be 0 to $40 \%$, and this value was lower than that of GV2. Mite-borne mo- saic virus was also observed in many fields, but the frequency of infection varied; it was $65 \%$ in field B, about $20 \%$ in fields $\mathrm{C}$ and $\mathrm{D}$, and less than $10 \%$ in fields $\mathrm{A}$ and $\mathrm{E}$. Interestingly, GV1 carlavirus was detected only in field A.

Meristem-tip derived cloves were cultivated for 3 to 5 years in fields F, G1, and $\mathrm{G} 2$, and symptomatic garlic plants accounted for 40,0 , and $8.3 \%$, respectively. The frequencies of GV2 potyvirus were 70 , 0 , and $8.3 \%$, respectively; whereas frequencies of mite-borne mosaic viruses were 10,0 , and $16 \%$, respectively. OYDV and GV1 carlavirus were not detected. Thus, the rates of re-infection differed greatly among both viruses and sites.
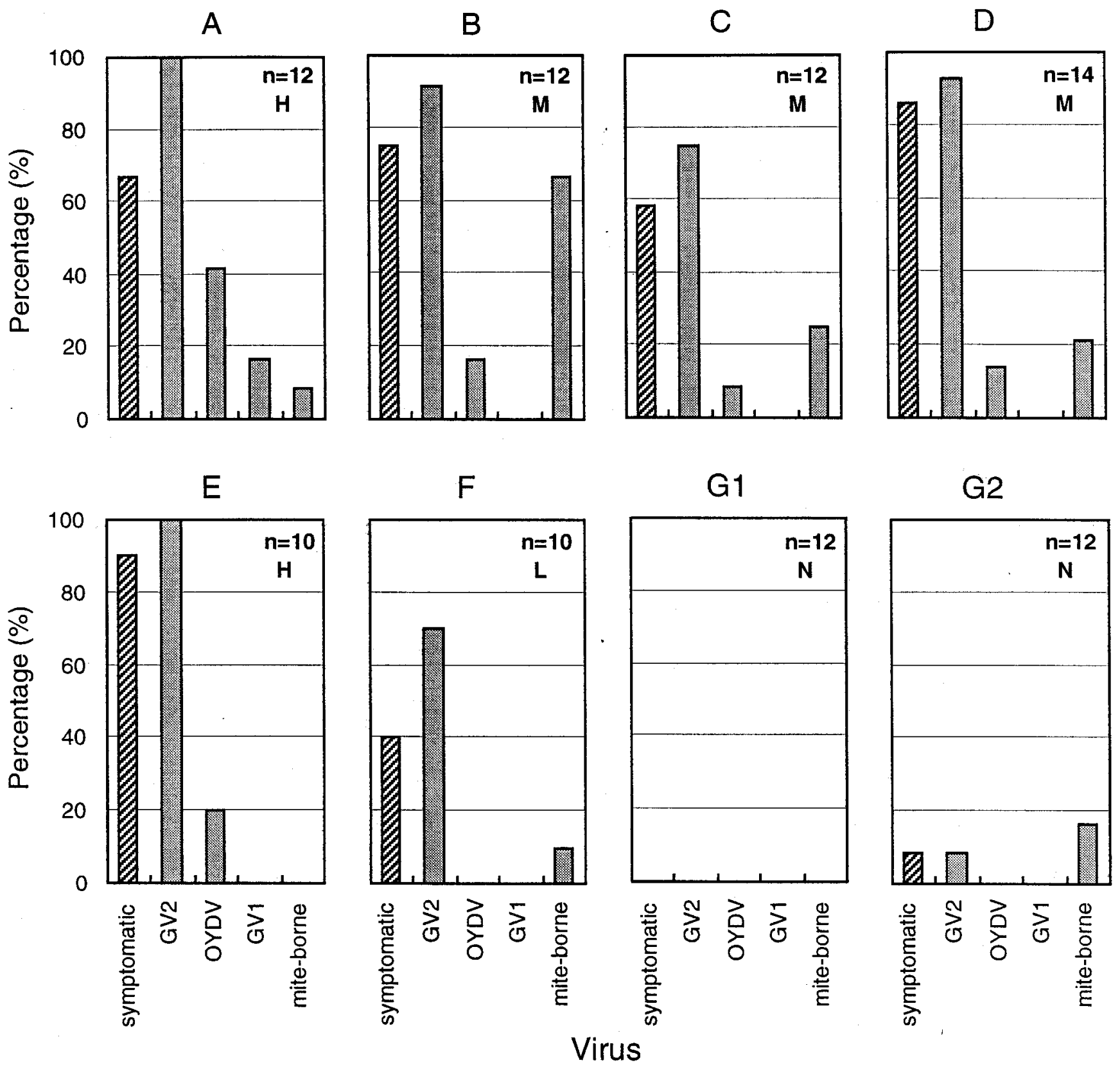

Fig. 4. Regional distributions of four viruses. Eight fields of seven regions (A to G) in Aomori Prefecture were selected, and garlic plants were tested using reverse transcription-polymerase chain reaction (RT-PCR). Ten to 14 plants per region were tested. $n=$ number of plants tested. The frequency of symptomatic garlic plants and the infection frequencies of GV1 carlavirus, GV2 potyvirus, onion yellow dwarf virus (OYDV), and mite-borne mosaic viruses are indicated. H, M, L, and N indicate degree of symptoms: high, medium, light, and none, respectively. 


\section{DISCUSSION}

We synthesized PCR primers for amplification of CP genes of GV1, GV2, OYDV, and mite-borne mosaic viruses, and developed an indexing method for these garlic viruses. With this method, only a small amount of leaf samples (about $50 \mathrm{mg}$ ) and specific single bands of the expected sizes were amplified in almost all combinations of primers when $0.5 \mu \mathrm{l}$ (about $0.1 \mathrm{ng}$ ) of cDNA was used as a template. Thus, RT-PCR is useful for indexing these garlic viruses.

GV2 potyvirus was detected at a high frequency in garlic plants from all fields A to $\mathrm{E}$ where local cloves were cultivated. The frequencies of disease symptoms were higher when frequencies of GV2 infection were high. Thus, GV2 is likely to be a major virus in garlic in Aomori Prefecture and the primary cause of disease symptoms. The Japanese garlic mosaic virus (1), which is thought to be GV2, has the same host range as LYSV (4). Recently, LYSV was isolated from Japanese garlic by other researchers $(16,27)$, and both viruses were identified as GV2 according to the nucleotide sequence data of Gene Bank. Thus, the GV2 potyvirus is thought to be LYSV. The CP gene of OYDV was isolated from garlic plants by Kobayashi et al. (8), but the nucleotide sequence showed no homology to GV2.

We detected OYDV using RT-PCR, but with a low frequency. In field $A$, both GV2- and OYDV-infected garlic plants showed the highest frequency $(40 \%)$, and the disease symptoms were heaviest among the seven regions (Table 1). Thus, severe disease symptoms were considered to be caused by a mixed infection of GV2 and OYDV. In other countries, the major potyviruses were found to be OYDV, and LYSV (GV2) was rarely detected (2,3,9, $11,12,17,18)$. Conversely, LYSV (GV2) is a major garlic virus, and OYDV is rare, in Aomori Prefecture.

The frequency of mite-borne mosaic viruses differs among fields. In fields B, C, and $\mathrm{D}$, both mite-borne mosaic viruses and GV2 potyvirus infected garlic plants at high frequencies (20 to $65 \%$ ), and symp-

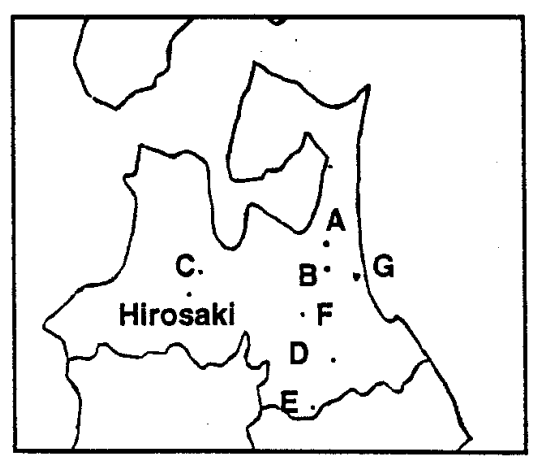

Fig. 5. Aomori Prefecture in northern Japan. Garlic plants in A to $G$ towns were tested by reverse transcription-polymerase chain reaction (RT-PCR). A = Tohoku, $\mathrm{B}=$ Tenmabayashi, $\mathrm{C}=$ Namioka, $\mathrm{D}=$ Shingo, $\mathrm{E}=$ Takko, $\mathrm{F}=$ Towada, $\mathrm{G}=$ Misawa. toms were fairly severe in case of mixinfection (Table 1). GV2 only infected garlic plants at a high frequency $(70 \%)$ in field $\mathrm{E}$, and symptoms were light (Table 1). Thus, a mixed infection with miteborne mosaic viruses and GV2 can lead to severe symptoms.

GV1 carlavirus was detected only in field A. Mixed infection of carlavirus and potyvirus has been considered to cause severe symptoms in garlic plants $(1,10)$. However, GV1 is not the major virus related to severe symptoms in the case of garlic grown in Aomori Prefecture.

Virus-free bulbs obtained by meristem tip culture are provided to farmers after several rounds of bulb propagation in the open field. Therefore, re-infection by viruses is a serious problem. The majority of the re-infected virus was GV2 (field F), which appears to cause disease symptoms, thus supporting the view that GV2 potyvirus is a major disease virus related to garlic mosaic symptoms. The decrease in yield and quality of garlic bulbs in field $\mathrm{F}$ was not a serious problem, because a single infection with GV2 does not lead to great yield reductions.

Rates of virus re-infection in virus-free cloves were reasonably low. Re-infection of viruses was not found in field $\mathrm{G}$, an isolated garlic field, and diseased garlic plants were not cultivated in the surrounding area. By contrast, re-infection by GV2 was observed in $70 \%$ of tested garlic plants in field F, which is in close proximity to the field used for production of garlic cloves.

The RT-PCR method facilitated indexing garlic viruses with high sensitivity and specificity and should prove useful to investigate the process of pathogenesis of garlic viruses.

\section{ACKNOWLEDGMENTS}

We thank M. Iwai and T. Chikahisa for technical assistance and M. Ohara for reviewing the manuscript.

\section{LITERATURE CITED}

1. Abiko, K., Watanabe, Y., and Nishi, Y. 1980. Studies on garlic mosaic. 1. Causal virus. Bull. Veg. Ornam. Crops Res. Stn. Jpn. Ser. A. 7:139-147.

2. Barg, E., Lesemann, D.-E., and Vetten, H. J. 1994. Identification, partial characterization, and distribution of viruses infecting Allium crops in south and southeast Asia. Acta Hortic. $358: 251-258$

3. Bellardi, M. G., Marani, F., Betti, L., and Rabiti, A. L. 1995. Detection of garlic common latent virus (GCLV) in Allium sativum $\mathrm{L}$. in Italy. Phytopathol. Mediterr. 34:58-61.

4. Bos, L. 1982. Viruses and virus diseases of Allium species. Acta Hortic. 127:11-29.

5. Dewan, C., Pearson, M. N., and Scheffer, J. J. C. 1995. Natural field infection of garlic by garlic yellow steak virus in the Pukekohe area of New Zealand and associated problems with the introduction of new garlic cultivars. N.Z. J. Crop Hortic. Sci. 23:97-102.

6. Fujisawa, I. 1989. Loss of garlic yield by double infection of garlic viruses. Agric. Hortic. 64:737-741.

7. Hwang, J. M., Chung, J. H., and Park, S. K. 1986. Yield performance test of virus-free garlic seed bulb (Allium sativum L.). Res. Rep. RDA (Hort) 28:24-31.

8. Kobayashi, K., Rabinowicz, P., Bravo-Almonacid, F., Helguera, M., Conci, V., Lot, H., and Mentaberry, A. 1996. Coat protein gene sequences of garlic and onion isolates of the onion yellow dwarf potyvirus (OYDV). Arch. Virol. 141:2277-2287.

9. Koch, M., and Salomon, R. 1994. Improvement of garlic via somaclonal variation and virus elimination. Acta Hortic. 358:211-214.

10. Lee, Y. W., Yamazaki, S., Osaki, T., and Inoue, T. 1979. Two elongated viruses in garlic: Garlic latent virus and garlic mosaic virus. Ann. Phytopathol. Soc. Jpn. 45:727-734.

11. Marys, E., Carballo, O., and Izaguirre-Mayoral, M. L. 1994. Isolation and characterization of viruses present in four clones of garlic (Allium sativum) in Venezuela. J. Phytopathol. $142: 227-234$.

12. Messiaen, C. M. 1994. Thirty years of France experience in production of disease-free garlic and shallot mother bulbs. Acta Hortic 358:275-279

13. Mohamed, N. A., and Young, B. R. 1981 Garlic yellow streak virus, a potyvirus infecting garlic in New Zealand. Ann. Appl. Biol. 97:65-74.

14. Nagakubo, T., Kubo, M., and Oeda, K. 1994 Nucleotide sequences of the $3^{\prime}$ regions of two major viruses from mosaic-diseased garlic. Molecular evidence of mixed infection by a potyvirus and a carlavirus. Phytopathology 84:640-645.

15. Ogawa, T., Matsubara, N., and Mori, N. 1976. Rearing of virus-free garlic. Agric. Hortic. 51:551-554.

16. Sumi, S., Tsuneyoshi, T., and Furutani, H. 1993. Novel rod-shaped viruses isolated from garlic, Allium sativum, possessing a unique genome organization. J. Gen. Virol. 74:1879-1885.

17. Sutarya, R. 1994. Virus disease of shallot and garlic in Java, and prospects for their control. Acta Hortic. 369:134-143.

18. Sward, R. J., and Brennan, A. P. 1994. Diagnosis and control Allium virus disease in Victoria, Australia. Acta Hortic. 358:295-298.

19. Tsuneyoshi, T., and Sumi, S. 1996. Differentiation among garlic viruses in mixed infections based on RT-PCR procedures and direct tissue blotting immunoassays. Phytopathology 86:253-259.

20. van Dijk, P. 1993. Survey and characterization of potyviruses and their strains of Allium species. Neth. J. Plant Pathol. 99:1-48.

21. van Dijk, P. 1993. Carlavirus isolated from cultivated Allium species represent three viruses. Neth. J. Plant Pathol. 99:233-257.

22. van Dijk, P. 1994. Virus disease of Allium species and products for their control. Acta Hortic. 358:299-305.

23. van Dijk, P., Verbeek, M., and Bos, L. 1991. Mite-borne virus isolates from cultivated $\mathrm{Al}$ lium species, and their classification into two new rymoviruses in the family Potyviridae. Neth. J. Plant Pathol. 97:381-399.

24. Walkey, D. G. A., and Antil, D. N. 1989 Agronomic evaluation of virus-free and virusinfected garlic (Allium sativum L.). J. Hortic. Sci. 64:53-60.

25. Walkey, D. G. A., Ebb, M. J. W., Ballooned, C. J., and Millar, A. 1987. Production of virus-free garlic (Allium sativum L.) and shallot (A. ascalonicum L.) by meristem-tip culture J. Hortic. Sci. 62:211-220.

26. Yamashita, K. 1992. Purification and serology of garlic mite-borne mosaic virus. (Abstr. Meet. Tohok Div. 1992) Ann. Phytopathol Soc. Jpn. 59:57.

27. Yamashita, K., Sakai, J., and Harada, K. 1996. Characterization of a new virus from Garlic (Allium sativum L.), garlic mite-borne mosaic virus. Ann. Phytopathol. Soc. Jpn. 62:483-489. 